\title{
MENGEMBANGKAN KECERDASAN MAJEMUK SISWA SEKOLAH DASAR (SD) MELALUI PEMBELAJARAN IPA UNTUK MENINGKATKAN MUTU LULUSAN SEKOLAH DASAR
}

\author{
Oleh \\ I Komang Wisnu Budi Wijaya \\ Institut Hindu Dharma Negeri Denpasar \\ wisnu.budiwijaya@yahoo.com
}

Diterima 4 Juli 2018, direvisi 26 Juli 2018, diterbitkan 31 Agustus 2018

\begin{abstract}
The progress of a nation is determined by the quality of Human Resources (HR). One characteristic of qualified human resources is to have multiple intelligences. Multiple intelligences consisting of linguistic, logical-reasoning, bodily kinesthetic, interpersonal, intrapersonal, musical, naturalist, and spatial. Development of multiple intelligences can be done since primary school, one of which is using science learning. The characteristics of the science learning process can allows the growth of multiple intelligences in primary school students.The development of multiple intelligences in primary schools requires important roles of teachers and schools. Multiple intelligences will help students to achieve the specified competency standards.
\end{abstract}

\section{Keywords : Intelligence, Multiple, Learning, Science, Primary School}

\section{PENDAHULUAN}

Kemajuan suatu bangsa ditentukan oleh kualitas Sumber Daya Manusia (SDM) yang dimiliki oleh bangsa itu sendiri. Oleh karena itu, pemerintah mencantumkan aspek pendidikan sebagai salah satu tujuan nasional yang terdapat dalam Pembukaan UndangUndang Dasar (UUD) 1945 yaitu mencerdaskan kehidupan bangsa. Dengan demikian, pemerintah membentuk suatu sistem pendidikan yang berskala nasional yaitu Sistem Pendidikan Nasional. Dengan demikian, diharapkan mampu membentuk manusia Indonesia yang seutuhnya yaitu manusia yang beriman dan bertaqwa kepada
Tuhan Yang Maha Esa, berakhlak mulia, sehat berilmu, cakap, kreatif, mandiri dan menjadi warga negara yang demokratis serta bertanggung jawab.

Manusia Indonesia yang utuh dapat terwujud apabila manusia Indonesia memiliki kecerdasan. Berbicara tentang kecerdasan, saat ini telah dicetuskan konsep kecerdasan majemuk (multiple intelegennce). Konsep kecerdasan majemuk diutarakan oleh Howard Gardner. Kecerdasan majemuk terdiri dari delapan macam yaitu kecerdasan verballinguistik, kecerdasan logis-matematis, kecerdasan visual-spasial, kecerdasan musikal, kecerdasan kinestetis, kecerdasan 
interpersonal, kecerdasan naturalis dan kecerdasan intrapersonal (Masfiroh, 2014). Kedelapan konsep kecerdasan ini diharapkan mampu mengubah paradigma guru tentang kecerdasan. Selama ini, guru memvonis siswa itu cerdas dan tidak cerdas hanya berdasarkan kemampuan logis-matematis semata. Padahal, intinya semua siswa itu cerdas hanya saja berbeda jenis kecerdasannya.

Pengembangan kecerdasan majemuk sangat penting dilakukan kepada peserta didik. Terlebih lagi di era globalisasi ini manusia dituntut untuk kaya akan kompetensi. Pengembangan kecerdasan majemuk sudah mulai dilakukan pada siswa sekolah dasar. Hal ini dikarenakan usia siswa di sekolah dasar adalah usia anak yang sedang mengalami perkembangan kognitif, sikap dan psikomotor dengan pesat.

Pengembangan kecerdasan majemuk dapat dilakukan dalam kegiatan pembelajaran. Salah satunya melalui pembelajaran IPA. Pembelajaran IPA pada hakekatnya dilakukan secara hands on dan minds on (Susilowati, 2013). Pembelajaran IPA bertujuan agar siswa memiliki keterampilan proses sains. Dalam pengembangan keterampilan proses sains ini, siswa secara tidak langsung dilatih untuk mengembangan kecerdasan majemuk.

\section{PEMBAHASAN}

\subsection{Kecerdasan Majemuk}

Konsep kecerdasan majemuk dikembangkan oleh Howard Gardner. Menurut Gardner, kecerdasan adalah suatu kemampuan atau kesanggupan menangani kandungan masalah yang spesifik di dunia. Poin-poin kunci dari teori Howard Gardner tentang kecerdasan majemuk adalah sebagai berikut :

1. Setiap orang memiliki delapan kecerdasan, hanya saja profil tiap orang mungkin berbeda. Ada yang tinggi pada semua jenis kecerdasan ada pula yang hanya rata-rata dan tinggi pada dua atau tiga jenis kecerdasan.

2. Orang dapat mengembangkan setiap kecerdasan sampai pada tingkat penguasaan yang memadai.
Kecerdasan dapat distimulai, dikembangkan sampai batas tertinggi melalui pengayaan, dukungan yang baik dan pengajaran.

3. Kecerdasan-kecerdasan umumnya bekerja bersamaan dengan cara yang kompleks. Dalam aktivitas seharihari, kecerdasan saling berkaitan dalam satu rangkaian misalnya ketika mengikuti pertandingan sepakbola terdapat aktivitas menendang bola (kinestetik), orientasi diri di lapangan (spasial) dan mengajukan protes kepada wasit (linguistik dan interpersonal).

4. Ada banyak cara untuk menjadi cerdas dalam setiap kategori. Misalnya seseorang yang cerdas secara linguistik mungkin tidak pandai menulis, tetapi pandai bercerita dan berbicara secara memukau (Masfiroh, 2014).

Kecerdasan majemuk terdiri dari kecerdasan verbal-linguistik, kecerdasan logis-matematis, kecerdasan visual-spasial, kecerdasan musikal, kecerdasan kinestetis, kecerdasan interpersonal, kecerdasan naturalis dan kecerdasan intrapersonal. Penjelasan masing-masing komponen adalah sebagai berikut :

1. Kecerdasan Verbal-Linguistik. Kecerdasan verbal-linguistik adalah kecerdasan seseorang berupa kepekaan pada bunyi, struktur, makna, fungsi kata dan bahasa. Ciriciri anak yang memiliki kecerdasan linguistik yang baik adalah bisa berkomunikasi secara lisan dan tulisan secara efektif, suka berdebat terkait suatu masalah, menguasai berbagai bahasa, pandai membuat karya sastra, mudah mengingat kutipan dan ucapan orang lain serta kaya akan kosa kata (Masfiroh, 2014).

2. Kecerdasan Logis-Matematis, adalah kecerdasan untuk mencerna sebuah pola logis, numerik serta mampu menalar sebuah alur berpikir yang panjang. Ciri-ciri anak yang memiliki kecerdasan logis-matematis adalah mampu menghitung dengan cepat, 
memprediksi, bereksperimen, menemukan sebuah pola dari suatu fenomena, bisa melakukan induksi dan deduksi terhadap berbagai permasalahan (Masfiroh, 2014).

3. Kecerdasan visual-spasial. Kecerdasan ini merupakan kemampuan untuk membuat sebuah desain atau persepsi dunia spasialvisual secara tepat. Anak yang mampu membuat sebuah desain bangunan atau areal, membaca peta dan chart, membuat karya dua dan tiga dimensi, mengkombinasi warna dengan baik adalah ciri anak yang memiliki kecerdasan visual-spasial (Masfiroh, 2014).

4. Kecerdasan kinestetis. Kecerdasan kinestetis adalah kemampuan untuk mengontrol dan mengatur gerak tubuh agar menarik. Anak yang memiliki kecerdasan kinestetis umumnya anak yang memiliki hobi yang berkaitan dengan gerak tubuh misalnya berolahraga, penari, mengukir dan hobi lainnya (Masfiroh, 2014).

5. Kecerdasan musikal. Kecerdasan musikal ditandai dengan kemampuan menciptakan dan mengapresiasi irama pola titi dan warna nada juga kemampuan mengapresiasi bentukbentuk ekspresi musikal. Ciri anak yang memiliki kecerdasan musikal adalah memiliki kesenangan dalam bernyanyi dan menghafal lagu-lagu, mampu memainkan alat musik dan kemampuan mengenali berbagai jenis suara di sekitarnya (Masfiroh, 2014).

6. Kecerdasan interpersonal. Kecerdasan interpersonal adalah kecerdasan untuk mencerna dan merespons secara tepat suasana hati, temperamen, motivasi dan keinginan orang lain. Anak yang memiliki kecerdasan interpersonal biasanya memiliki kemampuan untuk mengasuh dan mendidik orang lain, berkomunikasi secara efektif, bersimpati kepada orang lain, memimpin dan mengorganisasi orang lain dan bisa menjadi mediator konflik (Masfiroh, 2014).
7. Kecerdasan naturalis. Kecerdasan naturalis berkaitan dengan pemahaman tentang makhluk hidup lainnya serta eksistensinya. Anak yang memikiki kecerdasan naturalis umumnya mampu menganalisis persamaan dan perbedaan berbagai flora dan fauna, mengenali berbagai macam flora dan fauna, suka merawat berbagai jenis flora dan fauna dan melestarikan lingkungan (Masfiroh, 2014).

8. Kecerdasan intrapersonal. Kecerdasan interpersonal adalah kemampuan memahami perasaan sendiri dan kemampuan membedakan emosi, pengetahuan tentang kekuatan dan kelemahan diri. Seseorang yang cerdas interpersonal umumnya mampu memanajemen emosi dengan baik, memotivasi diri, tidak mudah putus asa dan lebih banyak bekerja daripada berbicara (Masfiroh, 2014).

\subsection{Pembelajaran IPA di Sekolah Dasar}

Pada hakekatnya, IPA dipandang sebagai proses dan sebagai produk (Prihantoro dalam Trianto, 2010). Sebagai proses, IPA diartikan semua kegiatan ilmiah untuk menyempurnakan pengetahuan tentang alam maupun untuk menemukan pengetahuan baru. Sebagai produk, IPA diartikan sebagai hasil proses, berupa pengetahuan yang diajarkan dalam sekolah atau di luar sekolah ataupun bahan bacaan untuk penyebaran pengetahuan. Sebagai aplikasi, teori-teori IPA akan melahirkan teknologi yang dapat memberi kemudahan bagi kehidupan (Trianto, 2010).

Jika menggunakan sudut pandang yang lebih menyeluruh, IPA dipandang sebagai cara berpikir ( $a$ way of thinking) untuk memeroleh pemahaman tentang alam dan sifat-sifatnya, cara untuk menyelidiki ( $a$ way of investigating) bagaimana fenomenafenomena alam dapat dijelaskan, sebagai batang tubuh pengetahuan ( $a$ body of knowledge) yang dihasilkan dari keingintahuan (inquiry) orang. Menggunakan pemahaman akan aspek-aspek yang fundamental ini, seorang guru sains (IPA) 
dapat terbantu ketika mereka menyampaikan pada para siswa gambaran yang lebih lengkap dan menyeluruh tentang semesta sains (Suryanti, 2009).

Pada jenjang pendidikan di sekolah dasar, mata pelajaran IPA menggunakan sistem terintegrasi dengan mata pelajaran lainnya yang disebut dengan pembelajaran tematik. Konsep IPA mulai masuk di pembelajaran tematik pada kelas IV sampai kelas VI. Alokasi waktu pembelajaran IPA di masingmasing kelas tersebut adalah sebanyak 3 jam pelajaran/minggu. Pemetaan materi pelajaran IPA di sekolah dasar disajikan dalam Tabel 1.

Tabel 1. Pemetaan Materi Pelajaran IPA di Sekolah Dasar

\begin{tabular}{|c|c|c|}
\hline No & Kelas & Materi \\
\hline 1 & IV & $\begin{array}{ll}\text { - } & \text { Makhluk Hidup } \\
\text { - } & \text { Gaya dan Gerak } \\
\text { - } & \text { Energi } \\
\text { - } & \text { Bunyi } \\
\text { - } & \text { Cahaya } \\
\text { - } & \text { Sumber Daya Alam } \\
\end{array}$ \\
\hline 2 & V & $\begin{array}{l}\text { - } \text { Rangka Manusia } \\
\text { - Tumbuhan } \\
\text { - Organ Tubuh Manusia dan Hewan } \\
\text { - Keseimbangan Lingkungan } \\
\text { - Listrik dan Magnet } \\
\text { - Siklus Air } \\
\text { - Rantai Makanan dan Ekosistem } \\
\text { - Sistem Pernafasan Manusia dan } \\
\text { Hewan }\end{array}$ \\
\hline 3 & VI & $\begin{array}{l}\text { - } \text { Energi Listrik } \\
\text { - Tata Surya } \\
\text { - Rotasi dan Revolusi Bumi } \\
\text { - } \text { Campuran dan Larutan } \\
\text { - Suhu dan Perubahan Wujud } \\
\text { - Perkembangbiakan Makhluk Hidup } \\
\text { - }\end{array}$ \\
\hline
\end{tabular}

\subsection{Strategi Meningkatkan Kecerdasan} Majemuk Melalui Pembelajaran IPA

Secara umum karakteristik pembelajaran

IPA di sekolah dasar adalah sebagai berikut :

1. Dilakukan dengan sistem belajar kelompok

2. Menggunakan prinsip hands on dan minds on

3. Melatih siswa terkait keterampilan proses sains

4. Fokus pada penanaman konsep, prinsip, hukum dan teori

5. Pembelajaran dilakukan di dalam dan luar kelas

6. Pembelajaran dilakukan secara menyenangkan dan berpusat siswa
Berdasarkan karakterstik tersebut, maka pembelajaran IPA memiliki potensi untuk mengembangkan kecerdasan majemuk siswa sekolah dasar. Berikut adalah penjelasan upaya meningkatkan kecerdasan majemuk siswa sekolah dasar melalui pembelajaran IPA.

\section{Kecerdasan Verbal-Linguistik}

Dalam pembelajaran IPA di sekolah dasar, kecerdasan verbal linguistik dapat dilatih dengan cara :

- Menerapkan sistem belajar kelompok. Dengan adanya sistem belajar kelompok, siswa akan terlatih untuk berkomunikasi secara lisan dengan kelompoknya serta 
mengkomunikasikan hasil diskusinya secara tertulis kepada guru.

- Menerapkan model pembelajaran berbasis masalah. Guru memberikan permasalahan terkait IPA dan meminta siswa mengutarakan gagasannya. Dalam proses ini tentu akan terjadi debat, sehingga siswa terlatih untuk menyanggah pendapat teman atau mempertahankan pendapat sendiri.

- Melatih siswa mengkomunikasikan pendapat/hasil diskusi di hadapn guru dan rekan-rekannya.

- Memberikan tugas membaca buku terkait IPA. Guru bisa menugaskan siswa untuk ke perpustakaan membaca buku referensi terkait topik IPA dan meringkasnya. Dengan demikian siswa akan terlatih untuk memahami struktur dan makna yang terkandung pada buku tersebut.

\section{Kecerdasan Matematis/Logis}

Pengembangan kecerdasan matematis logis dalam pembelajaran IPA dapat dilakukan dengan cara :

- Melaksanakan pembelajaran berbasis masalah. Guru memberikan masalah tak terstruktur kepada siswa untuk dicarikan solusinya. Dengan demikian, logika, nalar dan kemampuan siswa merancang strategi pemecahan masalah akan terlatih.

- Melatih siswa untuk memprediksi/memperkirakan.

Misalnya, setelah mempelajari tentang tumbuhan siswa dilatih untuk memprediksi tumbuhan mana yang lebih cepat tumbuh antara yang diletakkan di dalam ruangan dan di luar ruangan atau setelah mempelajari konsep rotasi dan revolusi bumi siswa dilatih untuk menentukan daerah mana yang mengalami siang dan malam pada posisi tertentu.

- Memberikan latihan soal yang bervariasi. Kecerdasan matematis logis siswa akan terlatih jika guru IPA sering memberikan latihan soal dengan variasi jenjang level kognitif yaitu pengetahuan, pemahaman, aplikasi, analisis, evaluasi dan kreasi.

\section{Kecerdasan Visual/Spasial}

Kecerdasan visual/spasial dapat dikembangkan dengan cara :

- Menyajikan data hasil percobaan dalam bentuk tabel/grafik. Dengan demikian, siswa akan terlatih untuk menata posisi variabel dalam grafik/tabel.

- Membuat kerajinan tangan yang berhubungan dengan IPA. Misalnya, membuat media pembelajaran Tata Surya dengan menggunakan benda bulat di sekitarnya atau membuat gambar manusia yang dilengkapi dengan organ tubuhnya.

\section{Kecerdasan Kinestetis}

Kecerdasan kinestetis dapat dikembangkan dengan cara mengajak siswa melakukan eksperimen sebagai bagian dari proses pembelajaran IPA. Dalam melaksanakan eksperimen, keterampilan proses sains siswa akan terlatih seperti melakukan observasi dan menggunakan alat dan bahan. Dengan demikian, siswa akan dilatih untuk terampil dan menyeimbangkan gerak motorik kasar dan halus.

\section{Kecerdasan Musikal}

Meskipun beda rumpun ilmu dengan IPA, namun kecerdasan musikal bisa dilatih dalam pembelajaran IPA dengan cara :

- Memberikan ice breaking berupa menyanyi bersama atau mendengar musik. Ice breaking adalah suatu kegiatan yang dilakukan guru di tengah pembelajaran untuk merelaksasi saraf otak siswa namun tetap menjaga konsentrasi siswa.

- Ketika mempelajari materi tentang Hewan, guru bisa menyisipkan kegiatan mengenal berbagai macam suara hewan.

\section{Kecerdasan Interpersonal}

Kecerdasan interpersonal dapat dilatih dengan cara melaksanakan kegiatan pembelajaran menggunakan model 
pembelajaran kooperatif. Ciri dari pembelajaran kooperatif adalah adanya tim yang bekerjasama untuk mencapai tujuan pembelajaran. Ketika siswa bergabung dalam sebuah tim maka siswa akan terlatih untuk berkomunikasi, berinteraksi, berorganisasi, memimpin dan memahami perbedaan sudut pandang. Model pembelajaran kooperatif yang bisa digunakan dalam pembelajaran IPA di sekolah dasar misalnya Jigsaw, STAD, Group Investigation dan Team Group Tournament (TGT).

\section{Kecerdasan Intrapersonal}

Kecerdasan intrapersonal berkaitan dengan kemampuan untuk memotivasi diri dan memanajemen emosi. Dalam pembelajaran IPA, kecerdasan ini dapat dilatih dengan cara :

- Memberikan tugas mandiri kepada siswa

- Senantiasa memotivasi siswa dalam belajar

- Menghadirkan nuansa konflik kognitif dalam kegiatan diskusi kelas

- Dalam melaksanakan belajar kelompok, guru membentuk kelompok secara heterogen

\section{Kecerdasan Naturalis}

Kecerdasan naturalis dicirikan dengan kepekaan dan pemahaman siswa tentang alam. Ini tentu sangat dekat dengan objek pembelajaran IPA. Kecerdasan naturalis dapat dikembangkan dengan cara :

- Melaksanakan pembelajaran IPA di luar kelas. Misalnya, ketika mempelajari tentang tumbuhan siswa diajak mengidentifikasi nama dan ciri tumbuhan yang ada di halaman sekolah.

- Menjelaskan pentingnya keberadaan tumbuhan dan hewan dalam keseimbangan alam dan kelangsungan hidup manusia sehingga timbul motivasi dalam diri siswa untuk melestarikannya.

- Memasang poster tentang keanekaragaman hayati di ruang kelas sehingga siswa mengenal berbagai jenis flora dan fauna.

\subsection{Peran Guru dan Sekolah dalam Pengembangan Kecerdasan Majemuk}

Pengembangan kecerdasan majemuk di sekolah dasar memerlukan peran guru dan sekolah. Peran yang dapat dilakukan adalah sebagai berikut :

- Guru melaksanakan pembelajaran berpusat siswa. Kecerdasan majemuk akan tumbuh jika siswa menjadi aktor utama dalam kegiatan pembelajaran. Kondisi di lapangan yang sering terjadi adalah pembelajaran justru dominan dilakukan oleh guru.

- Menggunakan media pembelajaran dan sumber belajar yang bervariasi. Siswa memiliki gaya belajar yang berbeda-beda yaitu visual, auditori dan kinestetik. Dengan menggunakan media dan sumber belajar yang bervariasi, maka siswa yang memiliki gaya belajar yang berbeda akan berkembang kecerdasan majemuknya.

- Sekolah senantiasa memfasilitasi perkembangan kecerdasan majemuk siswa dengan cara membuat berbagai jenis lomba intern dalam hari besar nasional dan keagamaan, mengadakan berbagai jenis ekstrakurikuler dan mengikutsertakan siswa dalam berbagai lomba.

\subsection{Kecerdasan Majemuk dan Kaitannya dengan Mutu Lulusan Sekolah Dasar}

Kurikulum 2013 sangat menekankan pencapaian dan peningkatan mutu lulusan di masing-masing jenjang pendidikan. Indikator dari mutu lulusan tersebut ditinjau berdasarkan tiga aspek yaitu sikap, pengetahuan dan keterampilan. Merujuk pada Permendikbud No. 20 Tahun 2016 tentang Standar Kompetensi Lulusan, standar kompetensi lulusan jenjang SD adalah sebagai berikut :

1. Memiliki perilaku yang mencerminkan sikap: 1. beriman dan bertakwa kepada Tuhan YME, 2. berkarakter, jujur, dan peduli, 3 . bertanggungjawab, 4 . pembelajar sejati sepanjang hayat, dan 5 . sehat jasmani dan rohani sesuai dengan perkembangan anak di lingkungan 
keluarga, sekolah, masyarakat dan lingkungan alam sekitar, bangsa, dan negara (dimensi sikap).

2. Memiliki pengetahuan faktual, konseptual, prosedural, dan metakognitif pada tingkat dasar berkenaan dengan: 1. ilmu pengetahuan, 2. teknologi, 3. seni, dan 4. Budaya serta mampu mengaitkan pengetahuan di atas dalam konteks diri sendiri, keluarga, sekolah, masyarakat dan lingkungan alam sekitar, bangsa, dan negara (dimensi pengetahuan).
3. Memiliki keterampilan berpikir dan bertindak: 1. kreatif, 2. produktif, 3 . kritis, 4. mandiri, 5. kolaboratif, dan 6. komunikatif melalui pendekatan ilmiah sesuai dengan tahap perkembangan anak yang relevan dengan tugas yang diberikan (dimensi keterampilan)

Untuk mencapai standar kompetensi lulusan tersebut, maka siswa sekolah dasar harus dibekali dengan delapan kecerdasan majemuk tersebut. Selain itu, standar kompetensi lulusan ini berkaitan erat dengan bagian dari kecerdasan majemuk. Keterkaitan tersebut disajikan dalam Tabel. 2

Tabel 2. Keterkaitan Antara Standar Kompetensi Lulusan Sekolah Dasar dengan Kecerdasan Majemuk

\begin{tabular}{|c|c|c|c|}
\hline No & Dimensi & Standar Kompetensi Lulusan & $\begin{array}{l}\text { Kecerdasan Majemuk } \\
\text { yang Diperlukan }\end{array}$ \\
\hline 1 & Sikap & $\begin{array}{l}\text { Memiliki perilaku yang mencerminkan } \\
\text { sikap: 1. beriman dan bertakwa kepada } \\
\text { Tuhan YME, 2. berkarakter, jujur, dan } \\
\text { peduli, 3. bertanggungjawab, } 4 . \\
\text { pembelajar sejati sepanjang hayat, dan } \\
5 \text {. sehat jasmani dan rohani sesuai } \\
\text { dengan perkembangan anak di } \\
\text { lingkungan keluarga, sekolah, } \\
\text { masyarakat dan lingkungan alam } \\
\text { sekitar, bangsa, dan negara (dimensi } \\
\text { sikap). }\end{array}$ & $\begin{array}{l}\text { Kecerdasan } \\
\text { interpersonal, } \\
\text { Kecerdasan } \\
\text { intrapersonal, } \\
\text { kecerdasan kinestetis } \\
\text { dan kecerdasan } \\
\text { linguistik }\end{array}$ \\
\hline 2 & Pengetahuan & $\begin{array}{l}\text { Memiliki pengetahuan faktual, } \\
\text { konseptual, prosedural, dan } \\
\text { metakognitif pada tingkat dasar } \\
\text { berkenaan dengan: 1. ilmu pengetahuan, } \\
\text { 2. teknologi, 3. seni, dan 4. Budaya serta } \\
\text { mampu mengaitkan pengetahuan di atas } \\
\text { dalam konteks diri sendiri, keluarga, } \\
\text { sekolah, masyarakat dan lingkungan } \\
\text { alam sekitar, bangsa, dan negara } \\
\text { (dimensi pengetahuan). }\end{array}$ & $\begin{array}{l}\text { Kecerdasan logis } \\
\text { matematis, kecerdasan } \\
\text { spasial, kecerdasan } \\
\text { linguistik, kecerdasan } \\
\text { visual-spasial dan } \\
\text { kecerdasan naturalis }\end{array}$ \\
\hline 3 & Keterampilan & $\begin{array}{l}\text { Memiliki keterampilan berpikir dan } \\
\text { bertindak: 1. kreatif, 2. produktif, } 3 . \\
\text { kritis, 4. mandiri, 5. kolaboratif, dan } 6 . \\
\text { komunikatif melalui pendekatan ilmiah } \\
\text { sesuai dengan tahap perkembangan anak } \\
\text { yang relevan dengan tugas yang } \\
\text { diberikan (dimensi keterampilan) }\end{array}$ & $\begin{array}{lr}\text { Kecerdasan } & \text { kinestetis, } \\
\text { kecerdasan } & \text { naturalis, } \\
\text { kecerdasan } & \text { spasial, } \\
\text { kecerdasan } & \text { lingusitik } \\
\text { dan kecerdasan spasial }\end{array}$ \\
\hline
\end{tabular}


Berdasarkan Tabel. 2, dapat disimpulkan bahwa sebenarnya siswa memerlukan kecerdasan majemuk untuk mencapai standar kompetensi lulusan yang telah ditetapkan sehingga mereka menjadi lulusan sekolah dasar yang memiliki kualitas secara utuh.

\section{SIMPULAN}

Semua siswa pada dasarnya memiliki kecerdasan majemuk, hanya saja berbeda mana yang menonjol. Pengembangan kecerdasan majemuk pada siswa sekolah dasar adalah momentum yang baik mengingat usia siswa sekolah dasar sedang mengalami perkembangan kognitif, sikap dan psikomotor. Pengembangan kecerdasan majemuk dapat dilakukan dalam pembelajaran IPA karena pembelajaran IPA memiliki karakteristik yang sesuai untuk pengembangan kecerdasan majemuk siswa.

\section{DAFTAR PUSTAKA}

Kemdikbud. (2013). Kurikulum 2013 Kompetensi Dasar SD/MI. Jakarta : Kementerian Pendidikan dan Kebudayaan
Musfiroh, T. (2014). Pengembangan Kecerdasan Majemuk. Jakarta : Universitas Terbuka

Permendikbud No. 20 Tahun 2016 tentang Standar Kompetensi Lulusan.

Suryanti. (2009). Hakekat Sains. Tersedia pada

blogsuryanti.files.wordpress.com/2009/0 6/hakikat-sains.doc. Diakses tanggal 18 Mei 2013.

Susilowati. (2013). Pembelajaran IPA dengan Hands-on Science Activity Berbasis Local Technology dalam Menyongsong Kurikulum 2013. Yogyakarta : Universitas Negeri Yogyakarta

Trianto. (2010). Model Pembelajaran Terpadu. Jakarta : PT. Bumi Aksara

Undang-Undang No. 20 Tahun 2003 tentang Sistem Pendidikan Nasional

Yuliantari, N. W. D. (2016). EMPAT PILAR PENDIDIKAN DALAM MENCIPTAKAN MUTU PENDIDIKAN YANG BERBUDAYA. Jurnal Penjaminan Mutu, 1(2), 16-24. 